\title{
Stopping the Real 'Cycle of Violence': A Feminist Critique of Patriarchal Battering and the Criminalization of Women by American Police Cathy Marston
}

The United States is one of the most violent societies in the world. Whether we like it or not, intend to or not, our society teaches children that it is ok to use violence to get what you want. We make violence look cool and sexy. The tougher you are the more people will respect you.

- Tapp 1992, p. 10

These people are trying to erase our pasts and destroy our futures.

- Merrie Lehning, incarcerated woman who killed her male batterer, serving a 52 year sentence in Texas.

According to the U.S. Department of Justice (2001) the United States has one of the highest rates in the world of domestic violence against women. An estimated $78-84 \%$ of American women are survivors of domestic violence These facts should not be surprising to anyone. What is surprising is how survivors are treated by the state, community and criminal justice system. In my research on the sexual harassment of female news workers, I found that male batterers / harassers / rapists employ four strategies when confronted with their misdeeds: 1) they lie; 2) they deny; 3) they blame the victim (say she "deserved" it); and 4) they call the victim "crazy" (Marston, 1993).

These victim-blaming strategies date back to the Burning Times, the mass gynocide/femicide by-fire of between 200,000 to 9 million women at the hands of those seeking to establish and further the then-nascent male-dominated church and 'medical' profession by murdering women healers, and goddess priestesses and worshippers (Budapest, 2007). In her book Witch: the Wild Ride from Wicked to Wicca, Canadian feminist historian Candace Savage (2000) juxtaposes the techniques and devices used to torture 'witches' with those being used to psychiatrize women today. Savage (2000, p. 71) writes that the witch and 'hysterical' women are discursively one and the same, and that while we have moved away from burning women at the stake, using ovarian compressions and uterus fumigators, we have not stopped psychiatrizing women. This paper will show that battered women are no longer only psychiatrised as hysterical for their reactions to the violence to which they are subjected to the hands 
of men, but that they are also criminalized and imprisoned as a result of their victimhood.

In fact, the Witch hunt can be considered to be ongoing in the U.S., especially in Texas. In Texas we can see this larger context of denial and blame playing out in the justice system's response to male violence against women. In the Lone Star state the fact is that on a domestic violence call, the Texas police arrest battered women instead of their male batterers at least 20 percent of the time, according to the Texas Council on Family Violence. This misogynist atrocity only happens 3 percent of the time in most other states. Consider these findings which suggest, unfortunately, Texas is not unique in its practice of criminalizing female survivors of domestic violence:

In Wichita, for example, women were $27 \%$ of those arrested for domestic violence in 2001 (Wichita Police Department, 2002). Prince William County, Maryland, saw the number of women arrested for domestic violence triple in a three-year period, with women going from 12.9 percent of those arrested in 1992 to 21 percent in 1996 (Smith, 1996). In Sacramento, even greater increases were observed; there, the number of women arrested for domestic violence rose by 91 percent between 1991 and 1996, whereas arrests of men fell 7 percent (Brown, 1997). Finally, a recent California study found that the female share of domestic violence arrests increased from 6 percent in 1988 to 16.5 percent in 1998 (Bureau of Criminal Information and Analysis, 1999). African-American girls and women had arrest rates roughly three times that of white girls and women in 1998: 149.6 compared with 46.4. (Chesney-Lind, 2002, p. 83).

These findings show that the problem is widespread, firmly entrenched in the U.S. criminal justice system, and that my experiences are part of the wider struggle of facing other criminalized survivors.

Gloria Steinem wrote in Revolution from Within (1992) that the only "violence" women commit is in the defence of themselves or their children. Indeed, this is not a crime, but a form of self-defence. Even Texas has a self-defence waiver in Chapter 9 of the Texas Penal Code. However, as Susan Faludi (1991) discusses in Backlash, some men believe that it is their right to control and beat women. For example, in 2007, the Philadelphia Women's Rights community voiced their disdain when the city hired and promoted male police officers with arrest records for committing battery 
(Police Beat, 2007). Therefore, it is not surprising that the mostly male American police forces are arresting battered women.

By arresting female survivors of battering, ${ }^{1}$ Texas is part of a misogynist jurisprudence and police practice that acts to empower some men to batter women with the knowledge that the police and courts will aid them in an ultimate act of victim-blaming: the arrest of the battered woman herself, slandering her, stigmatizing her as the problem, and silencing her through Texas' notorious prisons and jails. The incarceration of female abuse survivors is happening in Texas amid a longstanding nationwide movement to free and exonerate battered women in other states, as Ms. reported on the movement in its Fall 2007 issue in an article entitled "Freeing the Survivors". Even battered women who killed their batterers in self-defence are being freed and exonerated, but not here in Texas.

Why is it that states like California are leading the movement to free and exonerate battered women, while Texas is knuckle-dragging in the Dark Ages of patriarchal violence? The late feminist and Texan political writer, Molly Ivins (1971), explains what she calls "Lone Star state culture [as ...] a marriage of several strains of male chauvinism there is the machismo of our Latin tradition; the Southern belle concept of our confederate heritage; the pervasive good ol' boyism; the jock idolatry (football is not a game here, it is a matter of blood and death); and most important, the legacy of the frontier as it was when John Wayne lived on it". To the Texan male who already believes he is an outlaw cowboy, the woman's body is one more piece of territory to be colonized: to be literally wrangled and hogtied.

I know this because I have done five years on a ten-year sentence with no prior felony convictions for being a woman in a misogynist state that is completely out of touch with common decency, national jurisprudence and proper police practice. Twice in 2004, the Austin Police found my abusive ex-boyfriend and/or his best friend on top of me, beating me and trying to kill me. Both times the police intervened only to immediately arrest me without cause, failed to help me or to arrest my batterers. These officers showed little concern for my well-being and in fact laughed at me when they were not verbally abusing me. These incidents happened eleven months apart. The first took place on January 13, 2004 when my abusive ex-boyfriend tried to smother and choke me to death. There is evidence that he raped me while I was unconscious - I had bruises on my inner thighs. When I regained consciousness I reached for the phone to call 911. He then grabbed 
the phone out of my hand, which is a misdemeanour - "interference with a 911 call". When the operator answered, I screamed "HELP!", and he hungup the phone and beat me for ninety minutes. The police never came. It was only when he dragged me outside and recruited his friend to join in beating me that a neighbour called 911 and the Austin Police Department arrived, and found both men on top of me.

In the United States, the Fourth Amendment to the Constitution mandates that a citizen can only be arrested on probable cause. It also bans illegal searches, seizures and arrests. Chapter fourteen of the Texas Code of Criminal Procedure delineates the very few situations in which a peace officer can arrest someone without first going to a judge for a warrant. Witnessing a "crime in view", battering, and "interference with a 911 call" are a few of the scenarios under which Texas police may arrest without warrant. Subsequently, my arresting officer had to fabricate ex post facto probable cause for my arrest. I was originally charged with two misdemeanours: assault family violence and interference with a 911 call. By the time I was magistrated for bond, twelve hours later, the first charge was upgraded to a first degree felony for burglary. The second charge was intended to cover-up the fact that the police did not come when I screamed for help on the phone to 911.

On December 13, 2004 the abusive friend of my abusive ex-boyfriend chased me down in broad daylight. He tackled me and tried to kill me by grinding my face into the cement to smother me as he said, "Either I'll kill you first, or the cops will get you, you bitch!" That should turn your stomach and spark your outrage, as should the fact that this murderous man was right: as I was going unconscious and could taste the blood in my mouth from him tearing open my face, smothering me into the concrete, a police officer pulled-up to the curb five feet from my head. The officer laughed with my assailant, just as the January 13, 2004 arresting officer had done with this batterer and my abusive ex. Please note that in the original case my ex-boyfriend ran and got his friend to join in after beating me to a bruised, bloody mass and breaking my foot in two places. If the first unlawful arrest had been quickly and properly adjudicated to exonerate me and arrest my batterers, the second attempt on my life would never have occurred. Where would these abusive men get the idea that they could beat and kill a woman, and that the cops would arrest HER? From the larger American context of blaming women for the male violence committed against them and obviously from the Texas justice system. 
In her seminal book Backlash (1991), Susan Faludi reported that the largest growing group among the homeless in the 1980's were battered women who had fled their batterers with their children. Surely that group is even larger now, especially with the massive economic downturn of 2008-2009. This is largely due to the vulnerability of female workers in a sexist economy that still pays only 78 cents on a man's dollar and fewer benefits (Albeda, 2009). Also a result of living in a patriarchal society, sexist attitudes that force women to shoulder the blame for their own abuse assume that a woman can go to her father/parent for help, take for granted that a woman can easily apply for and live on public assistance, or pressure a woman to find another man to support her. In 2001, when I told friends I was being battered, the response was "Oh, you need to leave him" with no offer of support after I said, "I have no money and nowhere to go". I was advised to sell my property and leave my batterer - the onus was on me, as I was part of the problem for not leaving, not on my batterer for abusing me.

We cannot assume a battered women's shelter is an option for all women. They are underfunded and have limited space, making it difficult for some, particularly women with children, to seek refuge. We must also avoid telling a battered woman: "You need to sell all your property and leave" as if it is free to replace our property, and as if we do not have irreplaceable documents and mementos, and so on. I would have left my batterer a year earlier, in 2001, if I had had the money, safe housing, job and other support I needed to survive. After I left my batterer, the lack of much needed support and the lack of a well-paying job forced me to return to him for help. It was during this time that my mom disclosed the 40 years of abuse she had suffered at the hands of my dad. Battering is a community problem. Despite this there is little community support or understanding. For example, a potential employer of mine told me "good luck with your personal problem", knowing quite well that I was trying to get a financial foundation to move back to Texas to help my mom and knowing that I am, myself, a survivor of domestic violence.

In the United States, Domestic Violence Awareness Month falls in October, when Samhain/Hallowmas occurs, which is the most sacred Pagan Sabbat that honours the Pagan New Year and the Dead, including those murdered during the Burning Times (Savage, 2000; Budapest, 2007). This October and every day, citizens need to challenge the victimblaming of female survivors and help to STOP violence against women. To help bring about changes we must write Texas officials and demand 
they free and exonerate battered women like me. We must demand Texas legislators reinstate and expand Senate Committee Resolution 26 which was eradicated when George W. Bush became governor in 1994. SCR-26 created protections for battered women and created the Texas Council on Family Violence. The latter recommended pardons for battered women in the early 1990's during Governor Ann Richards' tenure, which the Board of Pardons and Paroles rejected. Write to President Obama and Vice President Biden and insist that they pay attention to this extremely pressing issue, and take action to end violence against women. We must tell Texas officials that the police arrest battered women and that the police who do arrest battered women, as well as the attorneys who prosecute them need to be held accountable for their complicity in allowing and perpetuating violence. Battering is a public safety emergency! Do not forget to demand generous monetary compensation, both from the state and batterers, for battered women's losses, injuries and time, jobs worthy of our educational and professional accomplishments, and sustainable, reasonable salaries for all battered women, as well as safe houses and communities to live in.

Black feminist cultural critic and writer bell hooks (2000) says that most Americans agree that they are against violence against women. However, as she points out in her book All About Love: New Visions, very few people want to put their beliefs into action to end battering. Why? As hooks (2000, p. 90) says, "When you explain that we can only end male violence by challenging patriarchy, and that means no longer accepting the notion that men should have more rights and privileges than women because of biological differences or that men should have the right to rule over women, that is when agreement stops". It is unthinkable and repugnant that people would not want to end battering especially since men often witness violence against their mothers or were themselves subject to male violence as children.

To end battering, we need to rethink gender roles and gender assumptions, as bell hooks (2000) suggests. We must quit thinking of women as belonging to their father, if single, or husband, if married. When a woman says she is being battered, the response should be, "I'm so sorry he's doing that. How can I help?" We should accompany the woman to make a police report or help her find shelter for herself and her children, protect her property, and we should provide on-going support. This paper has shown that the real "cycle of violence" emerges as a result of continued victim-blaming and patriarchal gender assumptions. Texas takes misogyny to its most violent extreme and to a uniquely unthinkable, repugnant conclusion: promoting 
domestic violence, instead of ending it. As the African proverb states, it takes a village to raise a child. Likewise, it takes a village to batter a woman and it will take a village to end battering.

When battered women stay, we as a community should look to see what we are doing to hinder the leaving process in order to make changes to facilitate their leaving and ultimate safety. When battered women are arrested instead of their male batterers, it is again the community's responsibility to insist that this outrage be stopped and that we follow through by holding public officials accountable.

\section{Justice is a Woman}

I.

Didja ever notice

how Justice is a woman?

Not a man

Not malecopsmalejudgesmalelawyers

Justice is a woman

Only malecopsmalejudgesmalelawyers

Could find a man battering a woman

(Well actually, find two men)

Call off the male batterer

Arrest the female victim

Slap their thighs with the batterer

Call the victim crazybelligerentguilty

As the blood pours out her nose,

Out her broken, bruised body

As she shivers from the

pain, the cold, the fear

Hands cuffed behind her back

II.

Jaw drops; wide-open eyes

Then kindly "Where does 


\author{
it hurt, ma'am?" asks \\ the black EMS tech. \\ "Everywhere!" I tell him. \\ "Where does it hurt the most?" snarls \\ Austin P.D.'s finest, the redneck white-boy \\ misogynist who arrested me \\ He coerces EMS out of taking me \\ to the hospital with visible head \\ trauma and broken bones \\ The Texas Council on Family Violence \\ reports that Texas cops deliberately \\ arrest battered women instead of \\ their male batterers at least \\ $20 \%$ of the time on a domestic violence \\ call where men commit \\ $99 \%$ of the domestic violence. \\ NO OTHER STATE OR COUNTRY DOES THIS
}

III.

"Quit the melodramatics! If

you DON'T get out and walk,

I'll get a jail guard and we'll

DRAG you!"

Austin P.D.'s finest again.

Limp. Limp. Limp.

My foot was broken

in 2 places. Not

that he or the jail

nurse cared. Had

to wait for an $\mathrm{x}$-ray

until I bonded out. APD

STILL wouldn't arrest Jack

(and Johnny) 
IV.

"Honey, where's the guy who did this to you?", asks the Travis County

Booking Officer.

"He's at home! Is it

the policy of the Austin police

to arrest the victim and leave

the batterer free?"

"That's NOT supposed to be their policy, ma'am"

Under the Texas Code of Criminal Procedure's Ch. 14

on Warrantless Arrests, it

clearly states that the police

are to arrest without warrant

on the spot, crimes committed

"in view" - especially domestic violence

The Fourth Amendment of the U\$ Constitution

bans illegal seizures/arrests. The $5^{\text {th }}$ and $14^{\text {th }}$

Amendments assure due process

and equal protection of law

V.

"So he's in here, right?

The guy who did this

to you?'

"No"

"Did APD take photos

of you?'

"No"

"Did APD take you

to the hospital?"

"No"

"What the hell is APD doing?" TCSO's

peace officer, exchanges glances 
with her 2 female cohorts.

She grabs a camera and snaps

20 color Polaroids of the

visible oozing bruising torn-

flesh injuries

But she DOESN'T go arrest

anyone

This is 12 hours after my arrest

That is NOT Justice

VI.

If Justice is a woman

then why am I here?

Merrie Lehning says,

"These people are trying

to erase our pasts and

destroy our futures"

That's NOT Justice!

Y'all have Her blindfolded

and handcuffed

And locked away from the public

to hide Her broken bones, Her

bruised, bleeding flesh

Give Justice a black cowgirl hat

and a lasso----

not scales and a blindfold!

Then She could see

what's going on

in Texas

and STOP it 
Justice

Is

A

Woman.

\section{ENDNOTES}

1 Marian Meyers (1994, p. 47) prefers the term battering because "terms such as family violence and domestic violence obscure the relationship between gender and power by failing to define the perpetrators and victims". In this paper, I speak of male violence against women.

\section{REFERENCES}

Albeda, Randy (2009) "Up With Women in the Downturn", Ms., 19(2): 34-37.

Brown, Mareva (1997) "Arrests of women soar in domestic assault cases", Sacramento Bee-December 7.

Bureau of Criminal Information and Analysis (1999) Report on Arrests for Domestic Violence in California, 1998, Sacramento California: Criminal Justice Statistics Center.

Chesney-Lind, Meda (2002) "Criminalizing Victimization: The Unintended Consequences of Pro-arrest Policies for Girls and Women", Criminology \& Public Policy, 2(1), 81-90.

Department of Justice (2001) Justice Works Fact Sheet, Washington (D.C.).

Faludi, S. (1991) Backlash: The Undeclared War Against American Women, New York: Crown.

Freeing the Survivors (2007) Ms., Fall, 19.

hooks, bell (2000) All About Love: New Visions, New York: William Morrow \& Co.

Ivins, Molly (1971) Lib in Longhorn Country, New York Times - October 18.

Marston, Cathy (1993) Sexual Harassment and Social Control in the Newsroom: Women's Narratives, Unpublished Master's Thesis, Austin: University of Texas at Austin.

Meyers, Marian (1994). "News of Battering", Journal of Communication, 44(2): 47-63.

Police Beat (2007) Ms., Fall.

Smith, Leef (1996) "Increasingly abuse shows a female side: More women accused of domestic violence", Washington Post - November 18, B1.

Steinem, Gloria (1992) Revolutions from Within: A Book of Self-esteem, Boston: Little Brown and Co.

Tapp, Anne M. (1992) "Forward", in Janice E. Rench, Family Violence: How to Recognize and Survive It, Minneapolis: Lerner.

Wichita Police Department (2002) Domestic Violence Statistics: 2001, retrieved from $<\mathrm{http}: / /$ wichitapolice.com/DV/DV_statistics.htm>. 


\section{ABOUT THE AUTHOR}

Cathy Marston Ph.D. is an internationally published feminist scholar, as well as an activist/agitator on disability rights and repetitive strain injuries. She is a former journalist and is currently imprisoned in the Texas Department of Criminal Justice, per the unlawful arrests alluded to in her poem "Justice is a Woman". This piece attempts to set this experience of sheer misogyny within a larger cultural framework via an inherent feminist critique of the patriarchal (in)justice system in the United States and in Texas in particular.

The author can be reached at:

Cathy Marston Ph.D., 1306127 LM

1916 N. HWY 36 Bypass

Gatesville, Texas 76596

USA 